\title{
Evidence based residential ventilation: sizing procedure and system solutions addressed by REHVA Residential Ventilation Task Force
}

\author{
Jarek Kurnitski1 ${ }^{1,2,}$, Martin Thalfeldt ${ }^{1}$, Harry van Weele, Macit Toksoy, Thomas Carlsson, Petra Vladykova Bednarova \\ and Olli Seppänen ${ }^{2}$ \\ ${ }^{1}$ Nearly Zero Energy Buildings Research Group, Ehitajate tee 5, 19086 Tallinn, Tallinn University of Technology, Estonia \\ ${ }^{2}$ Aalto University, School of Engineering, Rakentajanaukio 4 A, FI-02150 Espoo, Finland \\ ${ }^{3}$ ISSO, kennisinstituut voor de installatiesector, Weena 505, 3013 AL Rotterdam, The Netherlands \\ ${ }^{4}$ ENEKO, Ofisim İstanbul Plaza - Cevizli Mah. Tugay Yolu Caddesi B Blok No 18 D:40-41, 34846 Maltepe/İstanbul \\ ${ }^{5}$ MANN+HUMMEL, Schwieberdinger Straße 126, 71636 Ludwigsburg \\ ${ }^{6}$ Swegon Air Academy, Box 300 SE-535 23 Kvänum Sweden \\ ${ }^{7}$ The Finnish Association of HVAC Societies FINVAC ry, Sitratori 5, FIN-00420 Helsinki
}

\begin{abstract}
Wider application of heat recovery ventilation in residential buildings brings attention to knowledge and regulatory gaps which call for research and other actions. In many technical questions there is no consensus in national regulations of EU Member States (MS). This applies for instance for air flow rates, i.e. how much ventilation is needed, restrictions of the use of some heat exchangers types, connection of cooker hoods to ventilation system and placement of exhaust air devices. While European standards are well detailed in these aspects for non-residential ventilation, there is very limited information available for residential ventilation systems. Recent European Guidebook REHVA GB No 25 has made an attempt to collect evidence based best practice technical solutions and design principles for residential ventilation. In this paper a recent evidence and common assumptions behind REHVA airflow rate selection procedure is discussed. Best practice solutions and open research questions related to cooker hood connection to heat recovery and compensation to enable balanced operation of ventilation in an airtight building are analyzed. The paper summarizes existing evidence in these questions and defines open research questions for future residential ventilation research agenda.
\end{abstract}

\section{Introduction}

Energy performance of buildings has been continuously and systematically improved in Europe with next step of transition to nearly zero energy buildings (NZEB) in 2019-2021. Well insulated and airtight NZEB provide challenges or opportunities - depending on point of view - for ventilation systems. Heat recovery ventilation may be expected to be major ventilation solution because in Continental and Nordic climates, it is simply impossible to build nearly zero energy buildings without heat recovery. In warmer climates, co-benefits of heat recovery ventilation units as filtration of pollen and carcinogenic particulate matter (IARC 2014) [1] as well as sound insulation make it very strong alternative to conventional airing solutions, however this existing evidence is not yet widely accepted and understood (JRC 2016) [2]. The role of ventilation is twofold, in addition to energy saving contribution the main task of ventilation is to provide fresh air so that indoor air quality (IAQ) and thermal comfort are ensured. In well insulated and airtight buildings, the importance of controlled ventilation is stressed, because air infiltration through building envelope is practically missing and opening of windows during heating season will waste a big amount of energy.
In addition to supplying proper air flow rates, balanced operation and compensation of cooker hood, fireplace or central vacuum cleaner have new meaning in airtight buildings, that can be called as a security issue: if not properly designed for instance children are not able to open doors because of high pressure differences.

Wider application of heat recovery ventilation brings attention to knowledge and regulatory gaps which call for research and other actions. In EU level there have currently been no binding ventilation and IEQ requirements. From a regulatory point of view these remain under the competencies and responsibilities of the EU Member States, but the situation is changing. In the recent review process of Energy Performance of Buildings Directive (EPBD), the assessment of the implementation status of the EPBD by the EU MS in terms of ventilation and indoor air quality criteria was conducted by European Commission Joint Research Center [2]. This assessment confirmed that there still exist MS without binding ventilation requirements and many inadequate ventilation problems have been reported especially from renovations, where insulation, improvement of air tightness and replacement of windows has often stopped air change because adequate ventilation

* Corresponding author: jarek.kurnitski@taltech.ee 
systems have not been installed. On the other hand, the scientific literature review done by JRC [2] provided new evidence that mechanical heat recovery ventilation systems have led to an overall improvement of the IAQ and reduction of reported comfort and health related problems if properly designed and operated. This reveals that highly performing and healthy buildings do exist in EU and have improved occupant comfort and satisfaction. Revised EPBD stresses the importance of ventilation by requiring adequate ventilation in order to optimise health, IAQ and comfort levels defined by MS, which provides clear mandate to MS to establish minimum ventilation requirements for new buildings and major renovations to implement the directive.

In many technical questions there is no consensus in national regulations of EU Member States (MS). This applies for instance for air flow rates, i.e. how much ventilation is needed, restrictions of the use of some heat exchangers types, connection of cooker hoods to ventilation system and placement of exhaust air devices. While European standards are well detailed in these aspects for non-residential ventilation, there is very limited information available for residential ventilation systems. Recent European Guidebook (REHVA GB No 25) [3] have made an attempt to collect evidence based best practice technical solutions and design principles for residential ventilation. In this paper existing evidence on ventilation is assessed and airflow sizing procedure extending the existing ones is proposed.

Still huge research need remains, experience of the use of advanced ventilation systems is needed for further development of components, system solutions, control and operation strategies as well as proper sizing.

\section{Existing evidence on ventilation need in dwellings}

Ventilation need in dwellings is determined by different criteria, at least body odour/bioeffluents from occupants, humidity generation, building material and other emissions are to be taken into account. Because of multiple origin of pollution sources and complex effects, epidemiological field studies conducted in dwellings may be seen as the most reliable way to combine different sources and effects. Starting from perceived air quality which has especially intensively used for sizing ventilation in non-residential buildings but applies also with some limitations for residential buildings the existing evidence can be summarised as follows:

- Body odor/bioeffluents/perceived air quality 4, 7 and $10 \mathrm{~L} / \mathrm{s}$ pers in indoor climate categories III, II and I respectively. These values are in use in major indoor climate standards CR 1752:1998 [4], EN 167981:2018 [5] and ISO 17772-1:2017 [6].

- 0.5 ach in Nordic countries associated with house dust mites (Wargocki et al. 2002) [7]
- $\quad$ No effects on asthma and allergy when $\geq 0.37$ ach (7 $\mathrm{L} / \mathrm{s}$ pers) or $\mathrm{CO} 2 \leq 900 \mathrm{ppm}$ above outdoors (Bornehag et al. 2005) [8]

- Mechanical ventilation has system reduced allergic symptoms and asthma and RH showing positive effects of higher air change rate (Kovesi et al. 2009) [9], (Xu et al. 2010) [10], (Wright et al. 2009) [11]

- Reduction of ventilation rate from 0.5-0.8 ach to 0.40.5 ach did not have negative effect on SBS symptoms, but air was perceived as stuffy/poor (Engvall et al. 2005) [12]

- $\mathrm{CO}_{2} 1600$ ppm (total) no effects on acute health symptoms and mental performance (experiments to isolate bioeffluents, (Zhang et al. 2018) [13]

- Health based ventilation rate $4 \mathrm{~L} / \mathrm{s}$ pers recommended for the condition in which the only source of pollution are human occupation emitting bio-effluents (Carrer et al. 2018, HealthVent project) [14]

- 6-7 L/s pers (summary by Carrer et al. 2015) should apply in occupied rooms (bedrooms, living rooms), but the same amount of extract air is needed from wet rooms and kitchen (source control) [15]

Therefore, experiments isolating bioeffluents show lower airflow rate as $1600 \mathrm{ppm} \mathrm{CO}_{2}$ corresponds to 4.5 $\mathrm{L} / \mathrm{s}$ pers at normal 1.2 met activity level. In order to convert the air change rate values of field studies to $\mathrm{L} / \mathrm{s}$ per person values, occupant density should be known that is not always the case. If the air volume of full apartment is calculated, air change rate of 0.5 ach usually corresponds to $7 \mathrm{~L} / \mathrm{s}$ pers or more at common occupant densities. However, in bedrooms the air volumes are quite small and per person air flow rates can be smaller. For instance, in $15 \mathrm{~m}^{2} 2$ person bedroom 0.5 ach leads only to $5 \mathrm{~L} / \mathrm{s}$ pers if no mixing with the rest of apartment air is not considered that would apply with closed door.

It can be summarized that existing evidence shows lower air flow rates of 4-4.5 L/s pers when bioeffluents are isolated or when acute health symptoms only are considered. Epidemiological studies representing realistic mix of sources in dwellings however reach up to the second indoor climate category specification of $7 \mathrm{~L} / \mathrm{s}$ pers especially when perceived stuffy/poor air quality is considered, supporting the application of this value as a safe ventilation rate.

\section{Room-based air flow rates for design of ventilation}

Selection of air flow rates in dwellings has recently been updated in European and ISO standards, in EN 15251:2007 replaced with EN 16798-1:2018 [5] and ISO 17772-1:2017 [6]. However, the use of these standards in the sizing of air flow rates is not straightforward, because standards provide airflows in several indoor climate categories and supply air flow rates are given in L/s per person, while the number of occupants is typically not known information in the design.

To make a step forward, default occupancy, transfer air and indoor climate category II assumptions were 
applied in the following in order to develope a roombased airflow rate selection procedure where L/s per room values for different type and size of rooms are calculated with these default assumptions. In this way it is possible to end up with room-based supply and extract airflow rates which can be applied in practical design. Based on Category II $7 \mathrm{~L} / \mathrm{s}$ per person which is well supported by existing evidence, the room-based values shown in Table 1.

- Table 1. Minimum airflow rates in residences [3]. $1 \mathrm{~L} / \mathrm{s}=3.6 \mathrm{~m}^{3} / \mathrm{h}$.

\begin{tabular}{|c|c|c|c|}
\hline & $\begin{array}{l}\text { Supply airflow rate } \\
\mathrm{L} / \mathrm{s}\end{array}$ & $\begin{array}{l}\text { Extract airflow rate } \\
\mathrm{L} / \mathrm{s}\end{array}$ & Air velocity ${ }^{1} \mathrm{~m} / \mathrm{s}$ \\
\hline Living rooms ${ }^{2}>15 \mathrm{~m}^{2}$ & $8+0.27 \mathrm{~L} /\left(\mathrm{s} \cdot \mathrm{m}^{2}\right)$ & & 0.10 \\
\hline Bedrooms $>15 \mathrm{~m}^{2}$ & 14 & & 0.10 \\
\hline Living rooms and bedrooms $11-15 \mathrm{~m}^{2}$ & 12 & & 0.10 \\
\hline $\begin{array}{l}\text { Bedrooms }<11 \mathrm{~m}^{2}, 3 \mathrm{rd} \text { and successive } \\
\text { bedrooms in large apartments }\end{array}$ & 8 & & 0.10 \\
\hline WC & & 10 & \\
\hline Bathroom & & 15 & \\
\hline Bathroom in one room apartment & & 10 & \\
\hline Utility room & & 8 & \\
\hline Wardrobe and storage room & & 6 & \\
\hline Kitchen $^{3}$ & & 8 & \\
\hline Kitchen $^{3}$, one room apartment & & 6 & \\
\hline Kitchen, cooker hood in operation & & 25 & \\
\hline $\begin{array}{l}\text { Average airflow rate of a whole residence } \\
\mathrm{L} /\left(\mathrm{s} \mathrm{m}^{2}\right)\end{array}$ & & 0.42 & \\
\hline Staircase of an apartment building, $\mathrm{ACH}$ & & 0.5 & \\
\hline
\end{tabular}

${ }^{1}$ Maximum air velocity values apply at the design airflow rate and supply air temperature in heating season conditions, in boost mode higher velocities may be accepted, see section 2.2 .

${ }^{2}$ Transfer air from bedrooms may be reduced, $12 \mathrm{~L} / \mathrm{s}$ is the minimum value

${ }^{3}$ Airflow rate in the kitchen when cooker hood is not in operation

The airflow rate $0.42 \mathrm{~L} /\left(\mathrm{s} \mathrm{m}^{2}\right)$ correspond to $0.6 \mathrm{ACH}$ when the ceiling height is $2.52 \mathrm{~m}$. Depending on the floor plan, air supplied to bedrooms may serve the living room as transfer air. Air transferred from bedrooms may be subtracted from living room supply airflow rate, however the minimum value of the supply airflow rate is $12 \mathrm{~L} / \mathrm{s}$. Supply airflow rate in larger living rooms is calculated as a function of floor area. The bedroom value of $14 \mathrm{~L} / \mathrm{s}$ allows for two persons in bedrooms larger than $15 \mathrm{~m}^{2}$. In large apartments or houses $8 \mathrm{~L} / \mathrm{s}$ may be used for the third and subsequent bedrooms which are assumed to be designed for one person. If the smallest bedrooms $(8 \mathrm{~L} / \mathrm{s})$ are occupied by two people, the airflow rate is $4 \mathrm{~L} / \mathrm{s}$ per person that corresponds to satisfactory indoor climate category III.

The values in Table 1 lead to different total supply and total extract airflow rates which should be balanced so that the lower value is increased to equal the higher value. In small apartments it is typically the extract airflow that defines the total airflow rate and the supply airflow has to be increased accordingly. In large apartments with many bedrooms the total supply airflow rate is typically higher and the extract airflow rates are increased to balance the ventilation. The average airflow rate of the whole residence may determine the total airflow rate in the case of very large rooms. This can occur, for example, in large detached houses.

The minimum requirement for cooker hood operation is $25 \mathrm{~L} / \mathrm{s}$ and is particularly significant in the smallest apartments. In larger apartments the cooker hood boost airflow value of $30 \mathrm{~L} / \mathrm{s}$ is recommended as it leads to $75 \%$ odour removal efficiency in the case of effective hoods (typically meeting the needs of a reasonably large air volume). A more accurate way to determine the required boost airflow rate is to use the airflow of a selected hood product that gives $75 \%$ odour extraction, as recommended in standard EN 13141-3 [16].

The determination of airflow rates is shown in following two examples. Table 2 provides a sizing procedure in a 3-bedroom apartment and Table 3 for a one-bedroom apartment. The plans and design airflow rates are shown in Fig. 1. 
Table 2. Separate and mutual optimum envelope values, the white to dark grey backgrounds represent minimum to maximum values of the three

\begin{tabular}{|c|c|c|c|c|}
\hline \multirow[t]{2}{*}{ Room } & \multirow{2}{*}{$\begin{array}{r}\text { Area, } \\
\mathrm{m}^{2}\end{array}$} & \multicolumn{3}{|c|}{ Airflow rate, $\mathrm{L} / \mathrm{s}\left(\mathrm{m}^{3} / \mathrm{h}\right)$} \\
\hline & & Supply & Extract & $\begin{array}{c}\text { General air } \\
\text { change }\end{array}$ \\
\hline 1.1 Kitchen & 11.3 & - & $8(28.8)$ & \\
\hline 1.2 Bedroom & 11.1 & $12(43.2)$ & - & \\
\hline 1.3 Bedroom & 13.4 & $12(43.2)$ & - & \\
\hline 1.4 Bathroom & 2.8 & - & $15(54.0)$ & \\
\hline $1.5 \mathrm{WC}$ & 1.3 & - & $10(36.0)$ & \\
\hline 1.6 Corridor & 14.8 & - & - & \\
\hline 1.7 Bedroom & 10.9 & $8(28.8)$ & - & \\
\hline $\begin{array}{l}1.8 \text { Living } \\
\text { room }\end{array}$ & 13.6 & $12(43.2)$ & - & \\
\hline $\begin{array}{l}\text { Entire } \\
\text { apartment }\end{array}$ & 79.3 & - & - & $\begin{array}{c}79.3 \cdot 0.42=33 \\
(118.8)\end{array}$ \\
\hline Total & & $44(158.4)$ & $33(118.8)$ & $33(118.8)$ \\
\hline
\end{tabular}

The extract airflow rates are smaller than the supply and they are to be increased by $11 \mathrm{~L} / \mathrm{s}$. In this case this is done by increasing kitchen extract, resulting in design extract airflow rates:

- WC $10 \mathrm{~L} / \mathrm{s}$

- Bathroom $15 \mathrm{~L} / \mathrm{s}$

- Kitchen $8+11=19 \mathrm{~L} / \mathrm{s}$

This results in design total supply and extract airflow rates $44 \mathrm{~L} / \mathrm{s}$. This total airflow rate of $44 \mathrm{~L} / \mathrm{s}$ corresponds to 0.80 air changes per hour, which is quite high because of many small bedrooms and expected high occupant density in this 3-bedroom apartment.

Table 3. Airflow rate calculation in one bedroom apartment. The determining airflow rate is marked with bold.

\begin{tabular}{|c|c|c|c|c|}
\hline \multirow[t]{2}{*}{ Room } & \multirow{2}{*}{$\begin{array}{r}\text { Area, } \\
\mathrm{m}^{2}\end{array}$} & \multicolumn{3}{|c|}{ Airflow rate, $\mathrm{L} / \mathrm{s}\left(\mathrm{m}^{3} / \mathrm{h}\right)$} \\
\hline & & Supply & Extract & $\begin{array}{c}\text { General air } \\
\text { change }\end{array}$ \\
\hline 2.1 Room & 3.0 & - & - & \\
\hline 2.2 Kitchen & 9.3 & - & $8(28.8)$ & \\
\hline $\begin{array}{l}2.3 \text { Living } \\
\text { room }\end{array}$ & 16.2 & $12(43.2)$ & - & \\
\hline 2.4 Room & 3.7 & - & - & \\
\hline 2.5 Bathroom & 3.5 & - & $15(54.0)$ & \\
\hline 2.6 Bedroom & 11.5 & $12(43.2)$ & - & \\
\hline $\begin{array}{l}\text { Entire } \\
\quad \text { apartment }\end{array}$ & 47.2 & - & - & $\begin{array}{c}47.2 \cdot 0.42=20 \\
(72.0)\end{array}$ \\
\hline Total & & $24(86.4)$ & $23(82.8)$ & $20(72.0)$ \\
\hline
\end{tabular}

In this one bedroom apartment total supply and extract airflow rates are almost equal and one extract airflow rate has be increased by $1 \mathrm{~L} / \mathrm{s}$ to balance the ventilation. The total design airflow rate of $24 \mathrm{~L} / \mathrm{s}$ corresponds to $0.73 \mathrm{ach}$.

The total design airflow rates calculated in previous tables do not include the temporary boost from the cooker hood which is in the both cases $25 \mathrm{~L} / \mathrm{s}$. In 3-bedroom apartment this flow rate may be temporarily 'borrowed' from the other extracts if the cooker hood damper is opened and so a ventilation boost is not necessary. In small one-bedroom apartment boosting the ventilation and borrowing from other extracts is a reasonable solution to achieve $25 \mathrm{~L} / \mathrm{s}$ cooker hood airflow which implementation is described in next section.

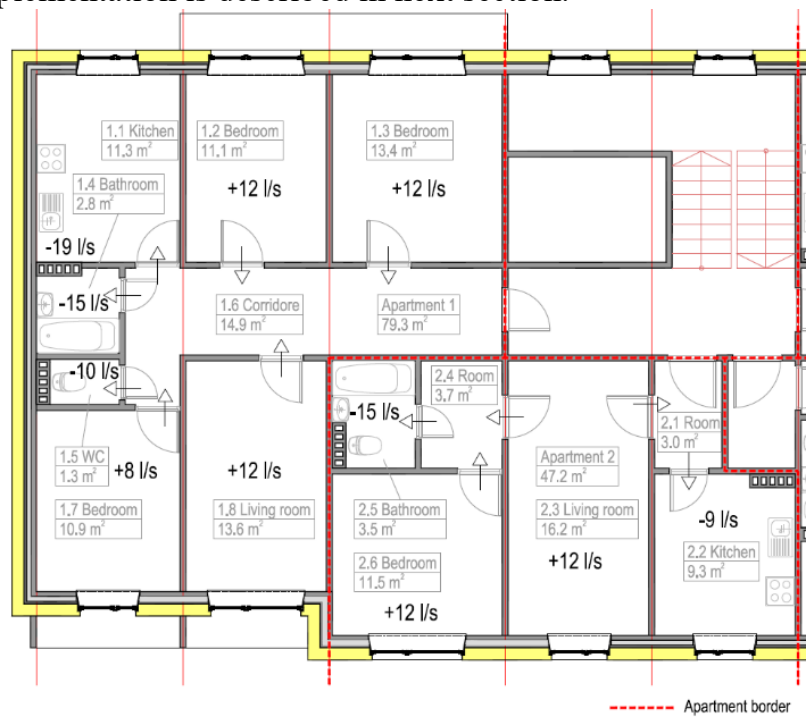

Fig. 1. Calculated airflow rates and transfer air paths in three and one-bedroom apartments.

\section{Ventilation system solutions for new low energy dwellings}

Air flow selection can be seen as an important, but only the first step in ventilation system configuration selection and system sizing. General principle of source control first, means that wet rooms are to be equipped with extracts and kitchens with cooker hoods. Supply air to living rooms and bedrooms has to be transferred and removed by these extracts. If conventional cooker hoods with their own exhaust fans are used, very high negative pressures up to $200 \mathrm{~Pa}$ may be generated depending on the building leakage rate as shown in Fig. 2.

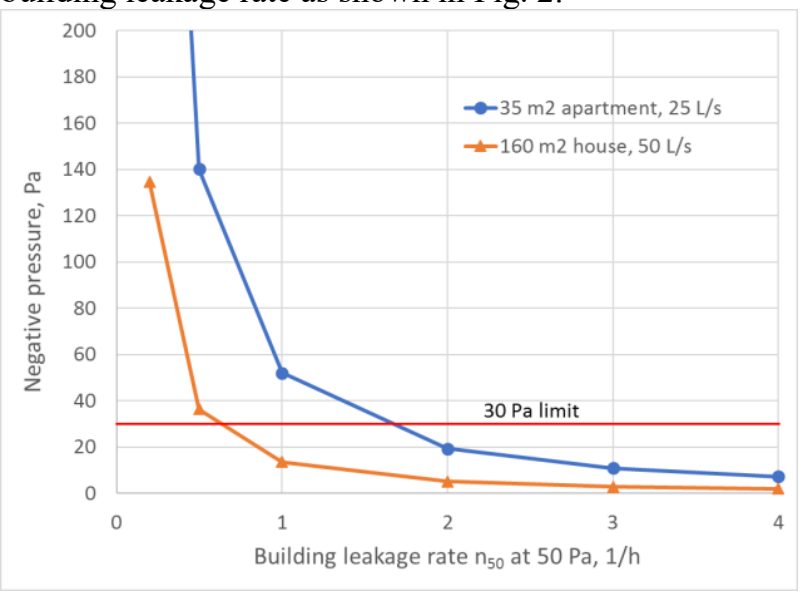

Fig. 2. Negative pressure generated by non-compensated cooker hoods, with flow rate of $25 \mathrm{~L} / \mathrm{s}$ in a $35 \mathrm{~m}^{2}$ apartment and $50 \mathrm{~L} / \mathrm{s}$ in a $160 \mathrm{~m}^{2}$ house, as a function of building leakage rate $\mathrm{n}_{50}$. Typical $\mathrm{n}_{50}$ values in modern airtight buildings are expected to be below $1(1 / \mathrm{h}) .30 \mathrm{~Pa}$ pressure difference limit (children cannot open doors) indicates that cooker hoods must be compensated in new buildings.

Therefore, to avoid excessive negative pressures, cooker hoods should be installed so that the balanced 
operation of ventilation system is ensured. This can be done by connecting cooker hood to ventilation unit, in the case plate heat exchanger the airflow from cooker hood will go through heat exchanger, but rotary heat exchangers are to be bypassed to avoid carry over of contaminants and to keep wheels clean.

A typical scheme is shown in Fig. 3Error! Reference source not found. with plate heat exchangers which allows the kitchen hood extract to be taken through the heat exchanger. It is recommended that the exhaust be ducted to the roof in order to avoid odour problems. Exhaust through the façade may be used, if local regulations allow, but in such a case exhaust air velocity and distances to adjacent apartment windows must be checked.

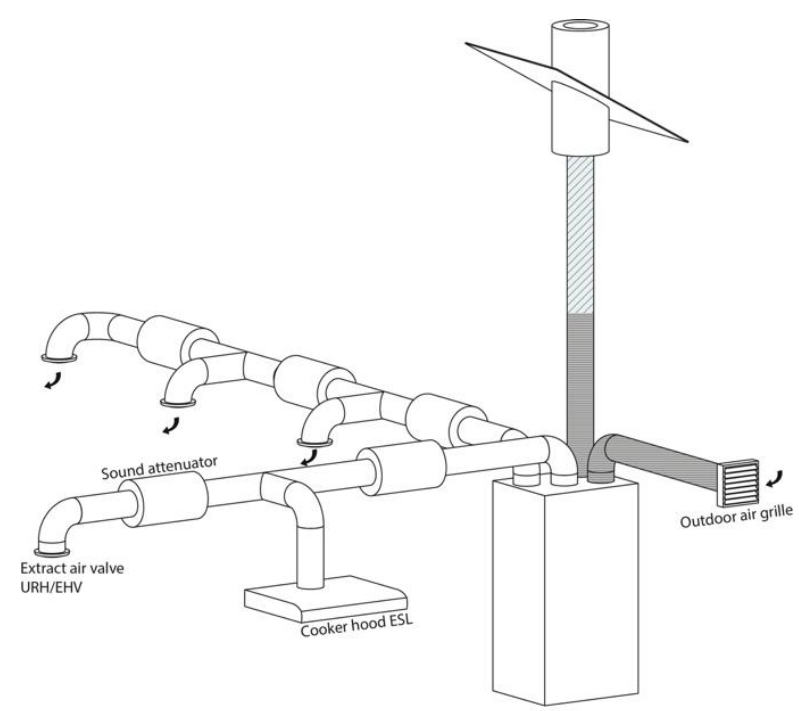

Fig. 3. Typical single dwelling ventilation unit. Outdoor air is taken directly from the facade, but exhaust is ducted to the roof, because the cooker hood is connected to the ventilation unit.

Where ventilation units include a rotary heat exchanger, the cooker hood will be connected after the heat exchanger and these units incorporate an extra duct connection for the cooker hood by-pass.

A typical centralized system layout is shown in Fig. 4Error! Reference source not found.. In such a system, plate heat exchangers are always used to avoid odour transfer in the heat recovery section. In modern systems, the air handling unit serves cooker hoods and constant pressure is maintained halfway between that of the supply and extract air main ducts. Opening the cooker hoods will increase extract airflow rate in the dwellings and the system increases the fan speed in order to keep constant static pressure in the main ducts. Opening of the cooker hood also causes some reduction in the other dwelling extract airflow rates (so called 'borrowing' principle). Ductwork is to be sized so as to at least achieve the required $25 \mathrm{~L} / \mathrm{s}$ from the cooker hood. A reasonable design assumption is that $70 \%$ of cooker hoods are operated at any one time. Typical pressure drops are shown in Fig. 5.

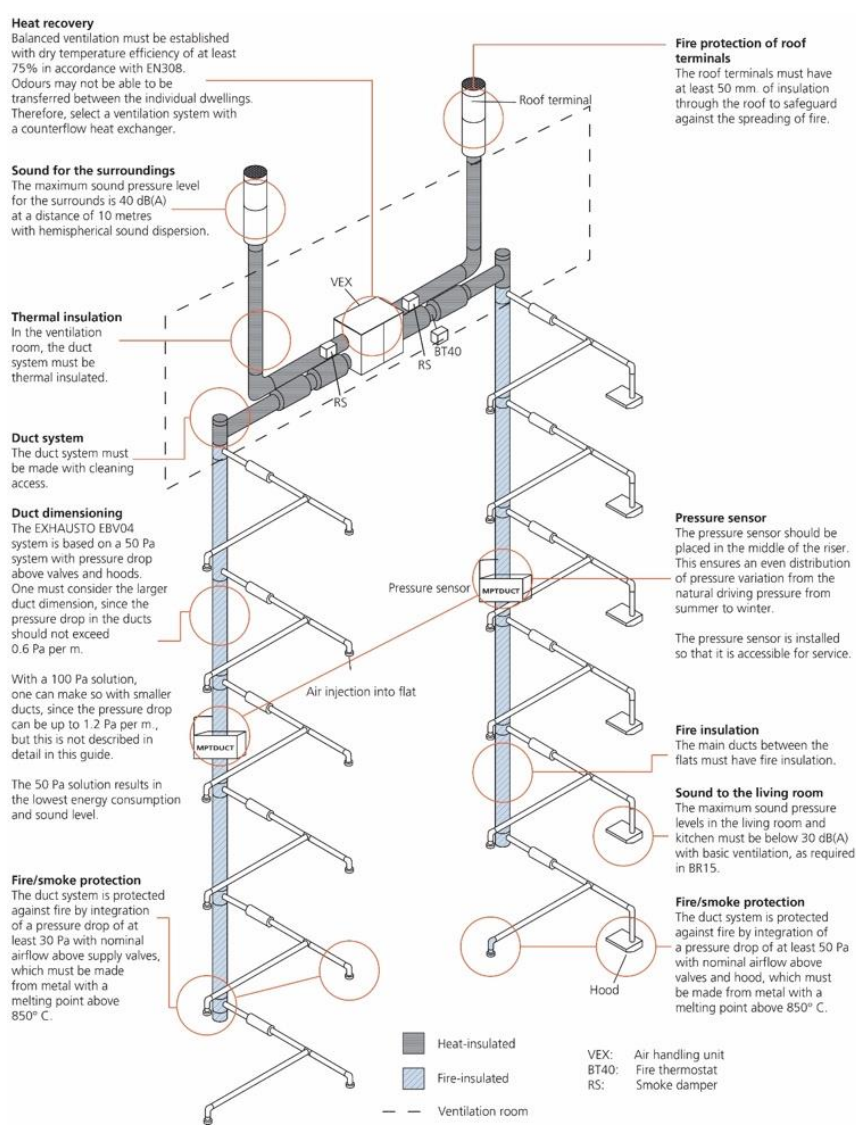

Fig. 4. Layout of the modern centralized system.

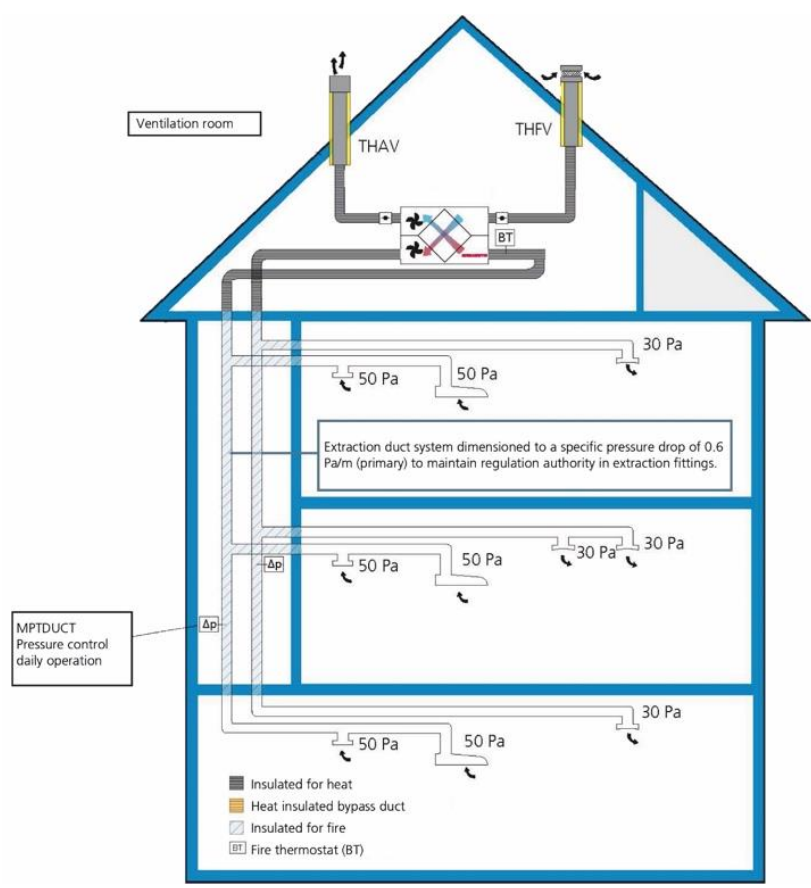

Fig. 5. Typical pressure drops in the ductwork.

In order to enable cooker hood extract air flow compensation, both in decentralized and centralized systems, a motorized damper is needed in the supply air ductwork. If the cooker hood damper is opened, the on/off damper in the supply air duct will open and the supply airflow rate is increased correspondingly, Fig. 6. To match the flow in the main extract duct, a pressure sensor 
in the main supply air duct will boost the centralized supply fan to maintain the constant pressure.

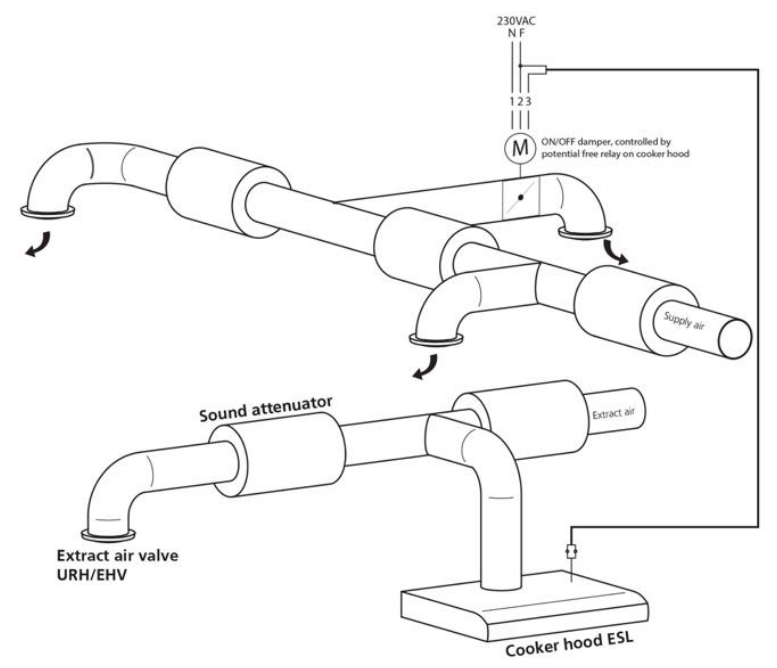

Fig. 6. Cooker hood extract airflow compensation principle with on/off damper and additional supply air damper.

Depending on the cooker hood used, it is possible to provide both general ventilation ( $\min 8 \mathrm{~L} / \mathrm{s}$ constant airflow) and boost (min $25 \mathrm{~L} / \mathrm{s})$ when the damper is opened via the cooker hood. General ventilation airflow (with the damper closed) can be adjusted by, for example, a magnetic strip on a perforated damper, determining how many holes are open. In the boost mode the damper will be opened, and if equipped with timer, it will be closed again after 60 minutes, if the occupant has not already closed it. The operating range of an example product is shown in Fig 7.

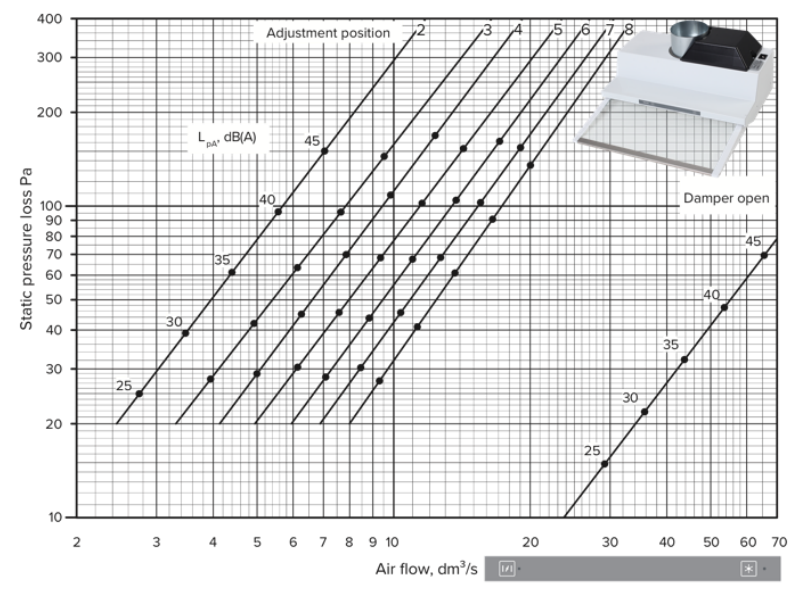

Fig. 7. Cooker hood operation range with closed (depending on adjustment) and open damper. The switch on the left opens the damper and the switch on the right is for the light.

Robust and reliable residential ventilation systems with minimal maintenance need have been generally recommended to have a continuous operation (CAV) however there are many technical solutions available for demand-controlled ventilation. Recent research has revealed that demand-controlled ventilation should be controlled in addition to bioeffluents and humidity generation also by other emission sources (VOC etc.) which do exist all the time. When these sources are taken into account much longer ventilation operation is needed compared to simple $\mathrm{CO}_{2}$ control. Walker and Brennan (2008) [17] have shown that instead of $40 \%$ energy saving only the saving in between $0-8 \%$ can be achieved depending on occupancy pattern and climate. It is important to notice that with residential air change rates close to 0.5 ach decay of concentration takes much more longer time than that in the case of non-residential ventilation typically by factor 3-4 higher ventilation rates, illustrated in Fig. 8. when ventilation is switched off for 6 hours.

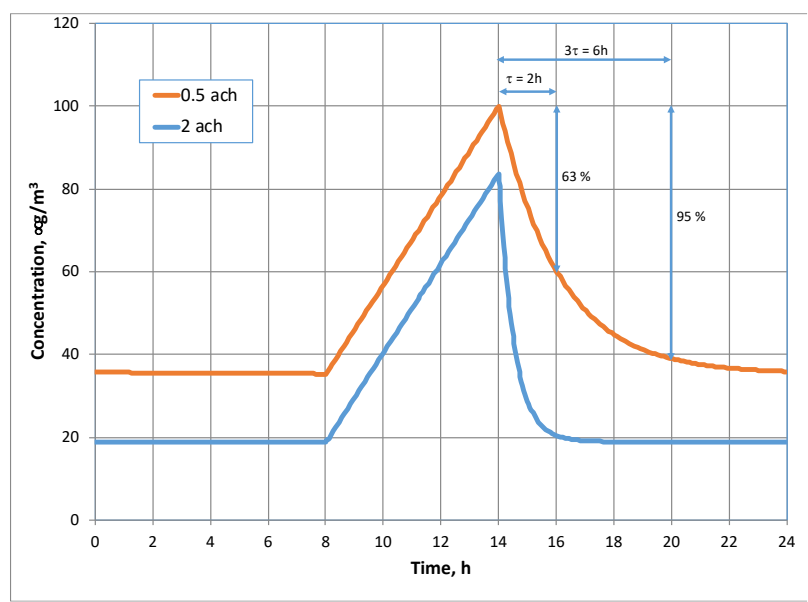

Fig. 8. Indoor concentration development with constant source when ventilation is switched off for 6 hours. In the case of 0.5 ach it takes $2 \mathrm{~h}$ to decrease by $63 \%$ ( 1 time constant) and $6 \mathrm{~h}$ by 95\% (3 time constants).

Therefore only small airflow reductions are possible during non-occupied hours and demand controlled ventilation systems should generally more focus to temporary boosting at high occupancy and overheating situations.

\section{Conclusions}

While European standards are well detailed for nonresidential ventilation, there is very limited information available for residential ventilation systems. Recent European Guidebook REHVA GB No 25 has collected evidence based best practice technical solutions and design principles for residential ventilation. Still huge research need remains, as experience of the use of advanced ventilation systems is needed for further development of components, system solutions, control and operation strategies as well as proper sizing.

Selection procedure of air flow rates in dwellings has recently been updated in European and ISO standards EN 16798-1:2018 and ISO 17772-1:2017. However, the use of these standards in the sizing of air flow rates is not straightforward, because standards provide airflows in several indoor climate categories and supply air flow rates are given in L/s per person, while the number of occupants is typically not known information in the design. REHVA GB No 25 has made a step forward by developing a roombased airflow rate selection procedure providing $\mathrm{L} / \mathrm{s}$ per room values for different type and size of rooms, which 
have been calculated with default occupant density range and indoor climate category II assumptions.

It is demonstrated that there is no conflict between good indoor climate and energy efficiency targets in airtight buildings if heat recovery ventilation is used. NZEB requirements provide new opportunities for dedicated ventilation systems and also a lot of research and harmonisation is needed in order to ensure robust and reliable operation of ventilation satisfying high level of occupant health and comfort requirements.

REHVA Residential Ventilation Task Force members and Eurovent Association are greatly acknowledged for the contribution to this European Guidebook. The research was supported by the Estonian Centre of Excellence in Zero Energy and Resource Efficient Smart Buildings and Districts, ZEBE, grant 2014-2020.4.01.15-0016 funded by the European Regional Development Fund.

\section{References}

[1] International Agency for Research on Cancer. IARC Monographs on the Evaluation of Carcinogenic Risks to Humans: vol. 109, Outdoor Air Pollution. Lyon, France: IARC; 2014.

[2] Promoting healthy and energy efficient buildings in the European Union. National implementation of related requirements of the Energy Performance Buildings Directive (2010/31/EU). Stylianos Kephalopoulos, Otmar Geiss, Josefa Barrero-Moreno, Delia D'Agostino, Daniele Paci. JRC Science for Policy Report 2016.

[3] Residential Heat Recovery Ventilation. Jarek Kurnitski (ed.), Martin Thalfeldt, Harry van Weele, Macit Toksoy, Thomas Carlsson, Petra Vladykova Bednarova, Olli Seppänen. European Guidebook No 25. REHVA 2018.

[4] CR 1752:1998, Indoor environmental input parameters for design and assessment of energy performance of buildings- addressing indoor air quality, thermal environment, lighting and acoustics.

[5] EN 16798-1:2018, Energy performance of buildings - Part 1: Indoor environmental input parameters for design and assessment of energy performance of buildings addressing indoor air quality, thermal environment, lighting and acoustics.

[6] ISO 17772-1:2017. Energy performance of buildings - Indoor environmental Quality Part 1: Indoor environmental input parameters for the design and assessment of energy performance of buildings.

[7] Wargocki, P., Sundell, J., Bischof, W., Brundrett, G., Fanger, P. O., Gyntelberg, F., Hanssen, S. O., Harrison, P., Pickering, A., Seppänen, O. and Wouters, P. Ventilation and Health in Nonindustrial Indoor Environments.
Report from a European Multidisciplinary Scientific Consensus Meeting', Indoor Air 2002, 12, 113-128

[8] Bornehag C.G., Sundell J., Hägerhed-Engman L., Sigsgaard T. Association between ventilation rates in 390 Swedish homes and allergic symptoms in children. Indoor Air 2005; 15: 275 280.

[9] Kovesi T., Zaloum C., Stocco C., Fugler D., Dales R.E., Ni A., Barrowman N., Gilbert N.L., Miller J.D. Heat recovery ventilators prevent respiratory disorders in Inuit children. Indoor Air 2009; 19: 489-499.

[10] Xu Y., Raja S., Ferro A.R., Jaques P.A., Hopke P.K., Gressani C., Wetzel L.E. Effectiveness of heating, ventilation and air conditioning system with HEPA filter unit on indoor air quality and asthmatic children's health. Building and Environment 2010; 45: 330-337.

[11] Wright G.R., Howieson S., McSharry C., McMahon A.D., Chaudhuri R., Thompson J., Donnelly I., Brooks R.G., Lawson A., Jolly L., McAlpine L., King E.M., Chapman M.D., Wood S., Thomson N.C. Effect of improved home ventilation on asthma control and house dust mite allergen levels. Allergy 2009: 64: 16711680.

[12] Engvall K., Wickman P., Norback D. Sick building syndrome and perceived indoor environment in relation to energy saving by reduced ventilation flow during heating season: a 1 year intervention study in dwellings. Indoor Air 2005; 15: 120-126.

[13] Xiaojing Zhang, Pawel Wargocki, Zhiwei Lian, Jingchao Xie, Jiaping Liu. The effects of bioeffluents on health symptoms, perceived air quality and cognitive performance -- summary of current evidence. In Proc. Indoor Air 2018.

[14] Paolo Carrer, Eduardo de Oliveira Fernandes, Hugo Santos, Otto Hänninen, Stylianos Kephalopoulos, Pawel Wargocki. On the Development of Health-Based Ventilation Guidelines: Principles and Framework. Int. J. Environ. Res. Public Health 2018, 15, 1360.

[15] Paolo Carrer, Pawel Wargocki, Annaclara Fanetti, Wolfgang Bischof, Eduardo De Oliveira Fernandes, Thomas Hartmann, Stylianos Kephalopoulos, Susanna Palkonen, Olli Seppänen. What does the scientific literature tell us about the ventilationehealth relationship in public and residential buildings? Building and Environment 94 (2015) 273-286.

[16] EN 13141-3:2017, Ventilation for buildings. Performance testing of components/products for residential ventilation - Part 3: Range hoods for residential use without fan.

[17] Iain Walker, Brennan Less. Reassessing Occupancy-Based Ventilation and IAQ in Homes. In Proc. Indoor Air 2018. 